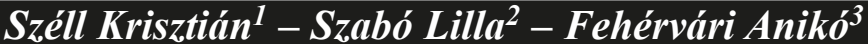

1, 2, 3 ELTE PPK Neveléstudományi Intézet

\section{Iskolai kötődés, iskolai klíma diák és pedagógus szemmel}

Tanulmányunk egy nagyobb kutatási projekt részeként született, amely a lemorzsolódás tanulói és iskolai tényezóit egyaránt vizsgálja. Az irás ebból a komplex, soktényezós rendszerból ragad ki egyet, az iskolai kötódést, klimát. Az iskolai kötódés, klíma és a tanulmányi eredményesség, illetve kudarc összefüggéseinek vizsgálata régóta tárgya az oktatáskutatásnak. Tanulmányunk

annyiban ad újat ehhez a diskurzushoz, hogy igyekszik a

különbözó fogalmakat, megközelítéseket együttesen kezelni, másrészt egyaránt fókuszál a tanulói és pedagógus nézópontokra.

\section{Elméleti háttér és kutatási előzmények}

\section{Tanulók iskolai kötődése}

A csoporthoz tartozás - legyen az iskola, család vagy bármilyen közösség - pozitívan befolyásolja az élettel való elégedettséget, az általános jóllétet, a pszichés és fizikai állapotot, valamint a kognitív teljesítményt (Allen és Bowles, 2012; Jetten és mtsai, 2017). A család mellett föképp az iskola teremti meg a lehetőségét annak, hogy a gyermekek tapasztalatokat szerezzenek a társas kapcsolatok müködéséröl, megélhessék a valahová tartozás érzését, ezért jelentős az iskola szerepe abban, hogy hozzásegítse a különböző hátterü és érdeklődésü gyermekeket ahhoz, hogy kapcsolódhassanak, és aktív részesei lehessenek a közösségnek.

Az iskolával és az iskolai közösséggel szemben kialakuló viszonyulás az együtt töltött idő és a tanulókat érő szociális-környezeti hatások révén ideális esetben elköteleződéssé (commitment), illetve a közösségbe, tanulásba való befektetéssé (investment) mélyülhet (Fredricks és mtsai, 2004), azonban, ha egy tanuló tartósan nem tud kapcsolódni az iskolához és az iskolai közösséghez, annak végső következménye a lemorzsolódás lehet (Lyche, 2010).

Számos kutatás megerősíti, hogy a tanulók iskolához való kötődése protektív tényező, mely elősegíti a szociális és tanulmányi sikerességet (Green és mtsai, 2012; Griffiths és mtsai, 2009), és szerepe jelentős a különböző iskolai problémák és a lemorzsolódás megelözésében, intervenciójában (Catalano és mtsai, 2004; Oelsner és mtsai, 2011; PinoJames és mtsai, 2019). Azáltal, hogy az iskolai kötődés az iskolai problémák kezelését és a lemorzsolódás prevencióját eredményesen támogatja, hozzájárulhat ahhoz, hogy minél kevesebb fiatal hagyja el az iskolát végzettség nélkül, így közvetve arra is hatással van, hogy minél alacsonyabb legyen a munkanélküliek és az alacsony jövedelemért dolgozók aránya, ami végső soron a szociális ellátórendszerre és a gazdaság egészére is hatást gyakorol (Rumberger és Rotermund, 2012). 
Az iskolai kötődésre vonatkozóan nincs egységes terminus és értelmezés a nemzetközi szakirodalomban: a school attachment, school bonding, school engagement, student engagement (with school), school connectedness, belonging to school kifejezések mind az iskolához való kötődést jelölik, azonban az elméletalkotók különböző tényezőket állítanak fókuszba (Fredricks és mtsai, 2004; Libbey, 2004). Egyes megközelítések csak egy-két tényező jelentőségét hangsúlyozzák az iskolai kötődés kialakulásában például Gottfredson (2001) a pedagógus-tanuló viszonyt -, a többség azonban komplex módon értelmezi a jelenséget. Nemzetközi vizsgálatokban gyakori az iskolai kötődés többdimenziós konstruktumként való megközelítése, annak affektív, viselkedéses és kognitív aspektusainak vizsgálata (Appleton és mtsai, 2008; Fredricks és mtsai, 2004). Jenkins (1997) szerint az iskolai kötődés főbb dimenziói az intézményhez füződő szoros érzelmi viszony, az intézménnyel szembeni elköteleződés, az aktív részvétel az iskola közösségi életében, valamint az iskola által megfogalmazott, képviselt normákba és értékekbe vetett hit. Ehhez nagyon hasonló Moody és Bearman (1998) megközelítése, akik szerint az iskolai kötődés olyan érzelmi állapot, melyben a tanuló azonosul az iskolájával, a közösség részének érzi magát, és kapcsolatokat épít ki a közösség más tagjaival. Értelmezésükben tehát az iskolai kötődés kialakulásában a pozitív érzelmi viszo-

Egyes megközelitések csak egykét tényezó jelentôségét hangsúlyozzák az iskolai kötôdés kialakulásában - például Gottfredson (2001) a pedagógus-tanuló viszonyt -, a többség azonban komplex módon értelmezi a jelenséget. Nemzetközi vizsgálatokban gyakori az isko-

lai kötôdés többdimenziós konstruktumként való megközelitése, annak affektiv, viselkedéses és kognitív aspektusainak vizsgálata (Appleton és mtsai, 2008; Fredricks és mtsai, 2004). Jenkins (1997) szerint az iskolai kötódés fóbb dimenziói az intézményhez fúzốdó szoros érzelmi viszony, az intézménynyel szembeni elkötelezódés, az aktív részvétel az iskola közösségi életében, valamint az iskola által megfogalmazott, képviselt normákba és értékekbe vetett hit. nyulás, az intézménnyel való azonosulás és a jól müködő közösségi kapcsolatok szerepe hangsúlyos. Az iskolai kötődés tehát nem a tanulóra jellemző sajátosság, sokkal inkább a tanuló aktuális - és adott esetben megváltoztatható - állapota, mely a környezeti hatások által erősen befolyásolt, ezért csak kontextusba ágyazottan értelmezhető (Allen és mtsai, 2018).

A tanulók iskolai kötődésének vizsgálata az 1980-as években indult útjára. E korai kutatásokat leginkább az unalom, az iskolától való elidegenedés és az iskolai lemorzsolódás hátterében álló tényezők megismerésének, e folyamatok megelőzésének sürgető törekvése hívta életre (Newmann, 1981, 1992; Newmann és mtsai, 1992). Mivel az iskolai kötődés olyan tényező az iskoláztatás ideje alatt, melynek szerepe a teljesítményt, személyiségfejlődést és viselkedést befolyásoló hatása miatt jelentős a különböző iskolai problémák és a lemorzsolódás megelőzésében (Catalano és mtsai, 2004), azóta is élénk kutatói érdeklődés övezi.

A hazai kutatások többnyire az iskolai kötődés egyéni sajátosságaival való összefüggéseit, hatásmechanizmusait vizsgálják, például kapcsolatát az iskolai aktivitással, normakövetéssel, tanulói énképpel, stresszel és teljesítménnyel (Szabó és Virányi, 2011), a társas kapcsolatrendszer kiterjedtségével (Nagy és Zsolnai, 2016) és a szándékos 
önszabályozással (Jámbori és mtsai, 2019). Bár nemzetközi térben is kurrens téma az iskolai kötődés tanulmányi eredményességgel (Bond és mtsai, 2007; Fleming és mtsai, 2005; Oelsner és mtsai, 2011) és szociális sikerességgel való összefüggéseinek (Davis, 2012; Juvonen és mtsai, 2012), valamint viselkedéssel (Frey és mtsai, 2008; Oelsner és mtsai, 2011) és jólléttel való kapcsolatának (Frydenberg és mtsai, 2009; Oldfiled és mtsai, 2015) vizsgálata, egyre több kutatási eredmény lát napvilágot az iskolai kötődés kontextuális meghatározottságával kapcsolatban (vö. Szabó, 2018). Ezek alapján mára elfogadott nézet, hogy az iskolai kötődés nem értelmezhető önmagában, csupán a kontextus viszonylatában (Allen és Kern, 2017; Fredricks és mtsai, 2004; Reschly és Christenson, 2012). Allen és munkatársai (2018) 51 empirikus tanulmány bevonásával készült metaelemzésükben megerősítették, hogy az iskolához való kötődést a tanuló egyéni sajátosságain kívül társas tényezők - kortárskapcsolatok, családi kapcsolatok, pedagógus-diák kapcsolat - és számos környezeti tényező is befolyásolja, például az iskola szervezeti sajátosságai, kapcsolatrendszere és politikai, kulturális, földrajzi környezetének sajátosságai.

Értelmezésünk szerint tehát az iskolai kötődés az iskola iránti pozitív érzelmi viszonyulás, állapot, mely magába foglalja a tanulók iskolai környezettel kapcsolatos érzelmeit, nézeteit, gondolatait, viselkedését, és nem csak egyéni, de kontextuális tényezők által is erösen meghatározott.

\section{Pedagógusok munka és szervezet iránti elkötelezödése}

A pedagógushivatás egyike a leginkább stresszel telített foglalkozásoknak, a kiégés a hazai pedagógusok körében is valós probléma (Mihálka és Pikó, 2018). Ugyanakkor a munkával kapcsolatban megélt boldogságnak számos, kifejezetten a munkához vagy a szervezethez köthető befolyásoló tényezője lehet, például az elvégzett munkára vonatkozó visszajelzés, a szervezethez tartozás érzése vagy a jó munkahelyi légkör (Kun és Szabó, 2017). A kutatási eredmények azt mutatják, hogy a munkájuk, illetve munkahelyük iránt elkötelezett pedagógusok kevésbé hajlamosak a kiégésre (Hakanen és mtsai, 2006) és a pályaelhagyásra (Smithers és Robinson, 2003).

A pedagógusok szervezeti elköteleződése ugyanakkor nem csak a pedagógusok jólléte szempontból releváns. A tanári hatékonyság és eredményesség - mely a tanulói teljesítményt jelentős mértékben meghatározó tényező - is összefüggést mutat a pedagógusok elköteleződésével (Bakker és Bal, 2010; Klassen és mtsai, 2012). Továbbá a munka iránti elköteleződés összefügg a produktivitással, munkahelyi tevékenységekben való részvétellel is, ami azt jelenti, hogy az elkötelezett pedagógusok nagyobbb valószínüséggel vesznek részt az iskola életében a tanítási tevékenységeken túl is (Bogler és Somech, 2004).

A pedagógusok iskolai elköteleződésének értelmezésekor is többféle megnevezéssel és fogalomértelmezéssel találkozunk, akárcsak a tanulói kötődés esetében. A pedagógusok munka iránti elkötelezettségét - melyet a nemzetközi szakirodalomban a work engagement és a teacher engagement (at work) kifejezések jelölnek - leggyakrabban Schaufeli és munkatársai (2006) meghatározása alapján definiálják (Hakanen és mtsai, 2012; Klassen és mtsai, 2012; Mérida-López és mtsai, 2017). Eszerint „a munka iránti elkötelezettség olyan pozitív, megelégedést nyújtó, munkával kapcsolatos tudatállapot, melyet lendület, odaadás és elmélyülés jellemez" (Schaufeli és mtsai, 2006. 702.). A munkájuk iránt elkötelezett pedagógusok energiát, időt szentelnek a feladatokra, erőfeszítéseket tesznek ezek elérésére, munkájukat fontosnak, jelentőségteljesnek látják és teljes figyelemmel végzik. Más kutatók a pedagógus-elköteleződés (teacher commitment) megnevezést alkalmazzák, és a jelenség affektív aspektusát hangsúlyozzák (Firestone és Pennell, 1993); eszerint a pedagógus-elköteleződés az adott személy számára különleges 
jelentéssel és jelentőséggel bíró „tárggyal” - professzióval, szervezettel és tanulókkal való azonosulás, érzelmi kapcsolódás. Somech és Bogler (2002) megközelítése szerint a pedagógus-elköteleződés két dimenzióját lehet megkülönböztetni: az egyik a szakmai elköteleződés (professional commitment), mely az egyén szakmájával kapcsolatos azonosulásának és bevonódásának relatív erősségeként értelmezhető (Morrow és Wirth, 1989, idézi: Somech és Bogler, 2002), a másik pedig a szervezet iránti elköteleződés (organizational commitment), mely az egyén egy adott szervezettel kapcsolatos identifikációjának és bevonódásának a relatív erőssége (Mowday, Steers és Porter, 1979, idézi: Somech és Bogler, 2002).

Az utóbbi években egyre több hazai vizsgálat foglalkozik a pedagógusok munkával, élettel való elégedettségével, jóllétével, és ezen jelenségeknek az iskola mint szervezet oldaláról történő megközelítésével (Mihálka és Pikó, 2018; Paksi és mtsai, 2015; Szabó és Jagodics, 2016). Mihálka és Pikó (2018) pedagógusok körében végzett kutatásából az derül ki, hogy a hazai pedagógusok körében is valós probléma a kiégés, melynek dimenziói - az érzelmi kimerültség, az elszemélytelenedés és a személyes teljesítmény csökkenése - negatívan függnek össze az élettel való elégedettséggel, az egészségi állapot önmegítélésével, és pozitívan a pszichoszomatikus tünetek gyakoriságával. A kiégés tehát mind a fizikai, mind a mentális egészséget veszélyezteti, sőt, közvetve a munkahelyi elégedettséget és elkötelezettséget is. A pedagógusok munkahelyi boldogságának és jóllétének vizsgálatakor Kun és Szabó (2017) több, kifejezetten a munkával és szervezettel kapcsolatos tényezőt azonosított, úgymint eredményesség és siker, a munkára vonatkozó értékelés és visszajelzés, a munkavégzés közben érzett öröm és motiváció, valamint a társas kapcsolatok. A közösen megélt élmények és sikerek a munkaközösség összetartó erejét jelentik, de az elkötelezettség és további motiváció megalapozói is (Kun és Szabó, 2017).

Louise és Smith (1992) szerint a pedagógusok elidegenedése alapvetően gátolja a tanulók iskolai kötődésének kialakulását. További vizsgálati eredmények alapján a munkájuk iránt elkötelezett pedagógusok énhatékonysága és érzelmi intelligenciája magasabb a kevésbé elkötelezett pedagógusokénál (Anari, 2012; Simbula és mtsai, 2011), illetve a tanulók iskolai kötődésének egyik erősen meghatározó tényezője a tanári támogatás megléte és erössége (Allen és mtsai, 2018).

Mindezek alapján megközelítésünk szerint a pedagógusok munka- és szervezeti elköteleződése (röviden pedagógus-elköteleződés) a professzió, az iskola mint szervezet, illetve a tanulók iránti pozitív érzelmi viszonyulás és a velük való azonosulás. A professzió iránti elköteleződés a pedagógusi minőséggel és szereppel való azonosulást és elégedettséget, a szervezet iránti elköteleződés a szervezet céljaival, értékeivel való azonosulást, míg a tanulók iránti elköteleződés a diákok tanulása és iskolai élete iránti felelősségvállalást és elhivatottságot jelenti (Firestone és Pennell, 1993; Mowday és mtsai, 1979; Park, 2005).

\section{Iskolai klíma}

Mint azt számos kutatás igazolja, a kognitív tudás nagyon fontos tényezője az eredményességnek, azonban ugyanilyen fontos a tudáshoz vezető út és az iskola informális tanulási környezete, klímája. A kölcsönös bizalmon alapuló pedagógus-diák kapcsolatok, a közösség tagjai közötti megértő és építő kommunikáció és az ezekből keletkező társadalmi, szociális, kapcsolati és kulturálistőke-előnyök - az uralkodó norma- és értékrendszeren, valamint elvárásokon keresztül - erős hatást gyakorolnak a tanulmányi eredményességre, a tanulók sikeres előrehaladására (Bourdieu, 1997; Bryk és Schneider, 2002; Coleman, 1988; Hargreaves és Fullan, 2012; Leana, 2010; Leana és Pil, 2006; Pusztai, 2009, 2015). 
Az iskolai klímára mint informális szervezeti jellemzőre vonatkozóan fogalomértelmezések széles körével találkozunk. A szervezetpszichológiai megközelítés szerint a szervezeti légkör (klíma) egy a csoport tagjaiban a fizikai környezettel, valamint a szervezet tagjaival való interakciók során kialakuló érzés. Cohen és munkatársai (2009) általános definíciójában az iskolai klíma a tanulók, pedagógusok, iskolavezetők és szülők iskolában folyó szociális, érzelmi, civil, etikai és tudományos életével függ össze, mely több mint személyes tapasztalat, inkább csoportos jelenségnek tekinthető. A szervezetszociológia előtérbe kerülésével egyre nagyobb hangsúlyt kapott a szervezeti klíma vizsgálata, amely koncepcionális megközelítést először Halpin és Croft (1963) alkalmazta iskolákra. Alapfeltevésük szerint a klíma kvázi olyan az iskolának, mint a személyiség az egyén számára, így az iskolai légkör az adott szereplők által észlelt szociálpszichológiai környezetben és kapcsolatrendszeren keresztül ragadható meg. Hasonlóan, Hoy és Miskel (2013) megközelítése szerint is az iskoláknak saját személyisége, karaktere van, leginkább pszichológiai perspektívából közelíthető meg. Anderson (1982) szerint is minden iskolának egyedi a légköre, mely igen összetett jelenség; bár nehéz mérni, szükséges, hiszen az iskolai klíma tanulmányozása megkönnyítheti a tanulói viselkedések megértését és előrejelzését, és befolyásolja a tanulók teljesítményét. A szervezetszociológia nézőpontja szerint tehát az iskolának sajátos légköre, arculata van, mely alapvetö hatással bír az iskola munkájára, az iskolában zajló folyamatokra és azok hatékonyságára, eredményességére. E sajátos, belső légkört az iskolába belépők észlelik, érzékelik, reagálnak rá, vagyis az iskolai klíma szubjektív jellegét az iskola tagjai formálják.

A kutatók többsége egyetért abban, hogy a légkör a különböző - müveltségi, szociális és fizikai - tényezők által meghatározott többdimenziós konstrukció (Bacskai, 2007, 2015; Balázs, 2014; Brand és mtsai, 2003; Cohen, 2012; Cohen és mtsai, 2009; Collins és Parson, 2010; Creemers és Reezigt, 1999; Pickeral és mtsai, 2009; Szabó, 2000; Thapa és mtsai, 2013). Bár az egyes megközelítések nem egységesek a dimenziók számában és abban, hogy mely tényezőket mely dimenziókhoz sorolják, többnyire ugyanazon légkörtényezők fontosságát emelik ki: a biztonságot, a kapcsolatok minőségét, valamint a tanulás, tanítás fejlesztési folyamatához köthető jellemzőket (Széll, 2018).

Az iskolai klíma vizsgálatát célzó kutatások fogalmi rendszere és kutatási megközelítése rendkívül szerteágazó az adott diszciplína, fogalomértelmezés, kérdésfelvetés és a szereplők percepciója szempontjából. A vizsgálatok fókusza alapján az iskolailégkör-vizsgálatoknak négy kutatási tradíciója különíthető el (Creemers és Reezigt, 1999): az iskolai klíma dimenzióira és jellemzőire irányuló iskolai hatások vizsgálatai, az eredményességkutatások, az osztálytermi hatások vizsgálatai és a pszichológiai jellemzők vizsgálatait célzó kutatások (vö. Széll, 2018).

A különböző aspektusok felől közelítő kutatások meggyőzően igazolják az iskolai légkör tanulói eredményességben betöltött szerepét. A kedvezö iskolai légkör pozitívan hat a kognitív és a nem kognitív tényezőkre, meghatározza a tanulók tanulmányi teljesítményét, szociális, érzelmi és mentális egészségét, viselkedését is (Bacskai, 2015; Brand és mtsai, 2003; Brookover és mtsai, 1978; Cohen és mtsai, 2009; Collins és Parson, 2010; Dronkers és Róbert, 2003; Fényes, 2008; Fényes és Pusztai, 2004; Freiberg, 1999; Griffith, 1995; Lannert, 2006; McMahon és mtsai, 2009; Papanastasiou, 2008; Pusztai, 2004, 2009, 2015). Továbbá az iskolai klíma meghatározó tényező az iskolai tevékenységekbe való bevonódás szempontjából, és hatással lehet a tanulók szubjektív jóllétére is (Lombardi és mtsai, 2019).

Az iskolaiklíma-kutatások a légkör pedagógusok jóllétében és az iskolák eredményességben betöltött szerepét is igazolják. A kedvezö, bizalommal teli iskolai légkör meghatározó szerepet játszik a tanári pályán maradásban (Kocsis, 2002; Paksi és mtsai, 2015), a kiégés elkerülésében (Paksi és Schmidt, 2006), valamint csökkenti a pályaelhagyás kockázatát is (Paksi és mtsai, 2015). Széll és munkatársai (2018) azt találták, hogy a 
magasabb légkörmutató - mely a tantestület oldottságát, rugalmasságát, nagyvonalúságát, haladóbb szellemiségét és inspirálóbb jellegét méri - a vezetők és a kollégák munkája, illetve a szervezet müködése, szakmaisága iránti magasabb bizalomérzettel jár együtt. A tanári szakmai közösségek és a tanárok közötti együttműködések, tapasztalatcserék pozitívan befolyásolják a diákok teljesítményét, továbbá ezek megléte csökkenti az etnikai és a szocio-ökonómiai státusz által meghatározott teljesítmények közötti szakadékot is (Moller és mtsai, 2013). Erre mutat rá Day és Gu (2014) is, akik szerint a tanárok, iskolák rugalmas és sikeres alkalmazkodóképessége sokkal inkább függ az iskola együttes szellemi, társadalmi és szervezeti környezetétől, mint a tanárok egyéni tulajdonságaitól, jellemvonásaitól.

Álláspontunk szerint tehát az iskolai légkör az iskola olyan jellegzetes karaktere, mely a megfogalmazott célok, normák és értékek, a megvalósuló oktató-nevelő munka színvonala, az interperszonális kapcsolatok, együttmüködések erőssége, kiterjedtsége és minősége, valamint az iskolai szereplők attitüdmintázatai függvényében határozza meg az iskolai élet minőségét (Széll, 2018). Az iskolai légkör tehát a szervezet olyan általános tulajdonsága, melynek érzékelhető hatása van az iskola hétköznapi életére.

\section{Az elemzés célja és kerete}

Az eddigiekben tárgyalt elméleti háttér és kutatási előzmények alapján látható, hogy az iskolai szereplők iskolához való kötődése és

A különbözó aspektusok felól közelitó kutatások meggyózóen igazolják az iskolai légkör tanulói eredményességben betöltött szerepét. A kedvezó iskolai légkör pozitivan hat a kognitiv és a nem kognitiv tényezókre, meghatározza a tanulók tanulmányi teljesitményét, szociális, érzelmi és mentális egészségét, viselkedését is (Bacskai, 2015;

Brand és mtsai, 2003;

Brookover és mtsai, 1978;

Cohen és mtsai, 2009; Collins és

Parson, 2010; Dronkers és Róbert, 2003; Fényes, 2008;

Fényes és Pusztai, 2004; Freiberg, 1999; Griffith, 1995; Lannert, 2006; McMahon és mtsai, 2009; Papanastasiou, 2008; Pusztai, 2004, 2009, 2015). Továbbá az iskolai klima meghatározó tényezó az iskolai tevékenységekbe való bevonódás szempontjából, és hatással lehet a tanulók szubjektív jóllétére is (Lombardi és mtsai, 2019). az általuk észlelt iskolai légkör között szoros kapcsolat áll fenn. Továbbá az előzőekben ismertetett kutatások egy része arra is felhívja a figyelmet, hogy az iskolai elköteleződés és az iskolai légkör erősen összefügg a tanulók, iskolák eredményességével, így hatással lehet az iskolai lemorzsolódásra is.

Jelen elemzés fó célja, hogy megvizsgálja, milyen eltérések mutatkoznak a tanulók és a pedagógusok véleményei között olyan területeken, amelyek alapvetően befolyásolhatják az iskolai lemorzsolódás mértékének alakulását. Így fő kutatási kérdésünk, hogy milyen különbségek mutatkoznak a diákok és a pedagógusok iskolai kötődésében, légkörészlelésében, valamint az ezen jellemzők megítéléséhez szorosan kötődő területeken - úgymint iskolai célok, elvárások és pedagóguskompetenciák, élettel való elégedettség és bizalom. További cél a vizsgált dimenziók közötti kapcsolatok erősségének feltárása, vizsgálata. 
Az elemzés alapját az iskolai lemorzsolódás hazai elemzését célzó komplex kutatás keretében 2018 őszén végzett online tanulói és pedagógus kérdőíves adatfelvételek eredményei adják (a kutatás főbb jellemzőit lásd az 1. táblázatban - a kutatásról, az adatfelvételek és a minták jellemzőiről, valamint az indexképzések módszeréről és eredményeiről bővebben lásd Fehérvári és mtsai, 2020). Mivel a kérdőíves adatfelvételekben hasonló kérdésekkel és az elemzés során is hasonló metódussal (főkomponens-elemzéssel) létrehozott indexek segítségével mértük a jelen tanulmányban vizsgált kérdésköröket, így össze tudjuk vetni az ezekkel a területekkel kapcsolatos tanulói és pedagógusvéleményeket.

1. táblázat. Az elemzés alapját adó kutatás föbb jellemzői

\begin{tabular}{|c|c|c|}
\hline & Tanulói adatfelvétel & Pedagógus adatfelvétel \\
\hline Adatfelvétel ideje & \multicolumn{2}{|c|}{ 2018/2019-es tanév, őszi félév } \\
\hline \multirow[t]{2}{*}{$\begin{array}{l}\text { Célpopuláció/ bruttó } \\
\text { minta }\end{array}$} & \multicolumn{2}{|c|}{$\begin{array}{c}\text { Három terület (Nyugat-Dunántúl, BAZ megye, Budapest) } \\
88 \text { általános iskolája (a projekt résztvevői) }\end{array}$} \\
\hline & 7. évfolyamos tanulói: 3431 fö" & pedagógusai: 2656 fö* \\
\hline Nettó minta & $\begin{array}{l}76 \text { feladatellátási hely } 1953 \\
\text { tanulója (elérési arány: } 56,9 \% \text { ) }\end{array}$ & $\begin{array}{c}75 \text { feladatellátási hely } 1136 \\
\text { pedagógusa (elérési arány: } 42,8 \% \text { ) }\end{array}$ \\
\hline Adatgyüjtési eljárás & \multicolumn{2}{|c|}{ Online kérdőíves adatfelvétel } \\
\hline Felhasznált adatok $^{* *}$ & \multicolumn{2}{|c|}{$\begin{array}{l}\text { Elköteleződés (bevonódás, kötődés) és légkörérzet } \\
\text { - Általános kötődés (index) (itemek: Szabó és Virányi, 2011) } \\
\text { - Interperszonális kötődés (index) (itemek: Szabó és Virányi, 2011) } \\
\text { - Közösségi bevonódás (egyedi item) (Rehbein és mtsai, 2013) } \\
\text { - Tantárgyi-tanulási / Tantárgyi-tanítási kötődés (index) (itemek: Szabó } \\
\text { és Virányi, 2011) } \\
\text { - Iskolai légkörérzet (index) (itemek: Sági, 2015; Széll, 2018) } \\
\text { Oktatási célok, elvárások és pedagóguskompetenciák } \\
\text { - Magas színvonal/elvárások (index) } \\
\text { - Tanulóra fordított figyelem (index) } \\
\text { - Tanulás kimenete (index) } \\
\text { - Pedagógusok felkészültségének megítélése (index) } \\
\text { - Pedagógusok digitális kompetenciájának megítélése (egyedi item) } \\
\text { Szubjektív jóllét } \\
\text { - Élettel való elégedettség - Cantril-létra (Cantril, 1965) (egyedi item) } \\
\text { - Bizalom (önmagában, jövőben) (egyedi itemek) }\end{array}$} \\
\hline
\end{tabular}

Megjegyzés: *2018. októberi KIR-STAT adatok. ${ }^{* *}$ Az adatokról, az indexek kialakításáról és tartalmáról lásd Fehérvári és munkatársai (2020).

Az elemzésben nem célunk az egyéni tanulói és pedagógus vélemények iskolai szintủ összevetése, ezért az elemzésbe bevontuk valamennyi 7. osztályos tanuló $(n=1953)$ és fö munkaviszonyban dolgozó pedagógus $(\mathrm{n}=1136)$ válaszait. Vagyis elemzésünkben eltekintettünk attól, hogy a tanulói, illetve a pedagógus adatfelvételben részt vevő általános iskolai feladatellátási helyek (76, illetve 75 iskola) nem teljesen fedik le egymást. 


\section{Az elemzés eredményei}

\section{Iskolai kötödés és légkörérzet}

A közösségi bevonódást, ${ }^{1}$ az iskolai kötődés három aldimenzióját (általános, interperszonális, tantárgyi-tanulási/tanítási kötődés), valamint az iskolai légkörérzetet vizsgálva megállapítható, hogy a tanulók és a pedagógusok körében is az osztályközösségbe, illetve tantestületbe való bevonódás mértéke a legmagasabb, mely szorosan kapcsolódik az interperszonális kötődés indexhez (tanulók esetén: $\mathrm{r}=0,511, \mathrm{p}<0,001$; pedagógusok esetén: $\mathrm{r}=0,475, \mathrm{p}<0,001)$, amely szintén magas mindkét vizsgált csoportban. A tanulók esetében ezt az iskolai légkörérzetük, a tantárgyakhoz, tanuláshoz való kötődésük, valamint az iskolához való általános kötődésük mértéke követi, míg a pedagógusok körében az iskolai légkörérzet indexértéke a legalacsonyabb, azaz azt megelözi a tantárgyakhoz, tanításhoz való kötődés és az általános kötődés mértéke is.

A pedagógusok interperszonális kötődése, azaz a kollégáikhoz füződő viszonya erősebb, mint a tanulók osztálytársakhoz füződő kapcsolata. Ezt jól mutatja az is, hogy a pedagógusok sokkal inkább bevonódnak a közösségük életébe, sokkal inkább érzik magukat a tantestület részének, fontos tagjának, mint a diákok a saját osztályközösségüknek. Hasonló mondható el a tantárgyakhoz, tanuláshoz/tanításhoz való kötődés kapcsán is: a pedagógusok több olyan tantárgyról és tantárgyi, tanítási tartalomról számoltak be, amelyeket szeretnek tanítani, mint a tanulók olyanról, amit szeretnek tanulni. Ugyanígy a pedagógusok iskola mint szervezet (munkahely) iránt érzett általános kötődése, azaz az iskolához, tanításhoz kapcsolódó pozitív, illetve negatív érzéseik összesített egyenlege (indexe) lényegesen pozitívabb képet mutat, mint a diákok iskolába járással kapcsolatos értékítélete.

Âltalánosságban tehát elmondható, hogy a tanulók közösségi bevonódása, iskolai kötődése és légkörérzete a független kétmintás t-próbák eredményei alapján szignifikánsan alacsonyabb, mint a pedagógusok közösségi bevonódása, munka és szervezet iránti elköteleződése, illetve légkörérzete. A szórásértékek azt is mutatják, hogy a pedagógusok véleménye némiképp egyöntetübb, mint a tanulók véleménye, ez alól egyedül az általános kötődés index jelent kivételt (2. táblázat).

2. táblázat. A tanulók és pedagógusok iskolához való kötődése és légkörérzete (0-100 fokú skálák átlagértéke és szórása)*

\begin{tabular}{|l|l|c|c|c|}
\hline \multicolumn{1}{|c|}{ Kérdéskör } & \multicolumn{1}{|c|}{ Minta } & $\mathbf{N}$ & Átlag & Szórás \\
\hline \multirow{2}{*}{ Osztályközösségbe / tantestületbe való bevonódás } & tanulói & 1898 & 76,3 & 26,70 \\
\cline { 2 - 5 } & pedagógus & 1052 & 84,4 & 18,56 \\
\hline \multirow{2}{*}{ Interperszonális kötődés } & tanulói & 1870 & 68,1 & 20,40 \\
\cline { 2 - 5 } & pedagógus & 1030 & 79,2 & 16,94 \\
\hline \multirow{2}{*}{ Tantárgyi-tanulási / tantárgyi-tanítási kötődés } & tanulói & 1862 & 58,6 & 22,91 \\
\cline { 2 - 5 } & pedagógus & 1026 & 76,1 & 20,14 \\
\hline \multirow{2}{*}{ Általános kötődés } & tanulói & 1818 & 54,0 & 21,21 \\
\cline { 2 - 5 } & pedagógus & 1024 & 73,8 & 23,40 \\
\hline \multirow{2}{*}{ Iskolai légkörérzet } & tanulói & 1766 & 61,4 & 19,99 \\
\cline { 2 - 5 } & pedagógus & 1012 & 71,2 & 17,02 \\
\hline
\end{tabular}

Megjegyzés: *A tanulók és a pedagógusok közötti különbségek vizsgálata független kétmintás t-próba alapján: $\mathrm{p}<0,001$. 
A korábbiakban ismertetett szakirodalom alapján is látható volt, hogy az iskolai kötődés és a légkör dimenziói nem különülnek el élesen egymástól, a különböző dimenziók alapvetően összefüggnek egymással. Eredményeink is jól mutatják, hogy mind a tanulók, mind a pedagógusok körében biztos, közepesen erős a kapcsolat a közösségi bevonódás, a kötődési dimenziók és a légkörérzet mutatói között. A diákok esetében a légkörérzet a legnagyobb mértékben a tantárgyi/tanulási kötődéssel függ össze $(r=0,589, \mathrm{p}<0,001)$, míg a pedagógusok körében egyértelműen az interperszonális kötődéssel mutatja a legszorosabb kapcsolatot $(\mathrm{r}=0,586, \mathrm{p}<0,001)$ (3. táblázat).

3. táblázat. A közösségi bevonódás, a kötődési aldimenziók és a légkörérzet közötti korrelációk*

\begin{tabular}{|c|c|c|c|c|c|}
\hline & $\begin{array}{l}\text { Közösségi } \\
\text { bevonódás }\end{array}$ & $\begin{array}{l}\text { Inter- } \\
\text { perszonális } \\
\text { kötődés }\end{array}$ & $\begin{array}{c}\text { Tantárgyi, } \\
\text { tanulási / } \\
\text { tanítási kötődés }\end{array}$ & $\begin{array}{c}\text { Általános } \\
\text { kötődés }\end{array}$ & $\begin{array}{c}\text { Iskolai } \\
\text { légkörérzet }\end{array}$ \\
\hline \multicolumn{6}{|c|}{ Tanulói } \\
\hline $\begin{array}{l}\text { Osztályközösségbe } \\
\text { való bevonódás }\end{array}$ & 1 & 0,511 & 0,179 & 0,182 & 0,244 \\
\hline $\begin{array}{l}\text { Interperszonális } \\
\text { kötődés }\end{array}$ & 0,511 & 1 & 0,421 & 0,351 & 0,437 \\
\hline $\begin{array}{l}\text { Tantárgyi, tanulási } \\
\text { kötődés }\end{array}$ & 0,179 & 0,421 & 1 & 0,526 & 0,589 \\
\hline Általános kötődés & 0,182 & 0,351 & 0,526 & 1 & 0,413 \\
\hline Iskolai légkörérzet & 0,244 & 0,437 & 0,589 & 0,413 & 1 \\
\hline \multicolumn{6}{|c|}{ Pedagógus } \\
\hline $\begin{array}{l}\text { Tantestületbe való } \\
\text { bevonódás }\end{array}$ & 1 & 0,475 & 0,239 & 0,274 & 0,326 \\
\hline $\begin{array}{l}\text { Interperszonális } \\
\text { kötődés }\end{array}$ & 0,475 & 1 & 0,544 & 0,488 & 0,586 \\
\hline $\begin{array}{l}\text { Tantárgyi, tanítási } \\
\text { kötődés }\end{array}$ & 0,239 & 0,544 & 1 & 0,418 & 0,424 \\
\hline Általános kötődés & 0,274 & 0,488 & 0,418 & 1 & 0,331 \\
\hline Iskolai légkörérzet & 0,326 & 0,586 & 0,424 & 0,331 & 1 \\
\hline
\end{tabular}

Megjegyzés: *Pearson-féle korrelációs együtthatókhoz tartozó szignifikanciaérték minden esetben $\mathrm{p}<0,001$. (A táblázatban a legalább közepesen erős, jelentős kapcsolatot mutató korrelációs együtthatókat $-\mathrm{r}>0,4-$ dőlten jelöltük.)

\section{Oktatási célok, elvárások és pedagóguskompetenciák}

Az iskolai kötődést és légkörérzetet nagymértékben befolyásolhatják az iskolát jellemző célok és elvárások, valamint az iskolában tanító pedagógusok szakmai kompetenciái. Az oktatási célokat, elvárásokat három dimenzió mentén vizsgáltuk: (1) magas oktatási színvonal és elvárások a tanulóktól és pedagógusoktól egyaránt, (2) tanuló-központúság (tanulókra - hátrányos helyzetüekre, tehetségesekre stb. - fordított figyelem), és (3) kimenet-központúság (tanulási kimenetek: továbbtanulásra, szakmaválasztásra történő felkészítés, tanulás tanítása). A pedagógusok felkészültségének vizsgálatakor igazodtunk a tanári felkészítés közös követelményeiről és az egyes tanárszakok képzési és kimeneti követelményeiről szóló 8/2013. (I. 30.) EMMI rendelet ${ }^{2}$ elöírásaihoz, amely 8 kompetenciaterületet jelöl meg: (1) a tanuló személyiségének fejlesztése, az egyéni bánásmód 
érvényesítése, (2) a tanulói csoportok, közösségek alakulásának segítése, fejlesztése, (3) a szakmódszertani és a szaktárgyi tudás, (4) a pedagógiai folyamat tervezése, (5) a tanulás támogatása, szervezése és irányítása, (6) a pedagógiai folyamatok és a tanulók értékelése, (7) a kommunikáció, a szakmai együttmüködés és a pályaidentitás, és (8) az autonómia és a felelősségvállalás. Ezen felül kilencedik elemként bevettük a digitális kompetenciát is, hogy milyen a pedagógusok felkészültsége a digitális technológiával támogatott tanítás és tanulás terén. Fontos kiemelni, hogy a pedagógusok digitális felkészültségének tanulók, illetve pedagógusok általi megítélése nem illeszkedett rá az eredeti 8 kompetenciaterület közös halmazára, azaz sem a főkomponens-elemzés kritériumai, sem a Cronbach alfa értékei alapján nem lehetett a 8 kompetenciaterülettel egy indexbe illeszteni. Ez azt is jelenti, hogy az eredeti 8 kompetenciaterület között összefüggés mutatkozik, míg a digitális kompetencia megléte (illetve megítélése) lényegében független a másik nyolc kompetenciaterülettől.

A tanulók szerint a kimenet-központúság, azaz a továbbtanulásra, szakmaválasztásra való felkészítés és a tanulás megtanítása a leginkább jellemző az iskolájukra, a tanuló-központúság, valamint a magas oktatási színvonal és elvárások jelenléte kevésbé jellemző, de az ezekkel kapcsolatos értékítéletek is inkább magasnak mondhatók. Utóbbiakhoz hasonló szintre értékelik iskolájuk pedagógusainak felkészültségét is, hozzátéve, hogy a digitális pedagóguskompetencia kapta a legkedvezőtlenebb értékelést a diákoktól. A pedagógusok ezzel szemben saját felkészültségüket tartják a legkiemelkedőbbnek, s a tanulóközpontúságot gondolják a legjellemzőbbnek az iskolájukban, melyet a kimenet-központúság és a magas szintü oktatás és elvárás követ. A diákokhoz hasonlóan a pedagógusok esetében is a saját digitális kompetencia területe kapta a legkisebb értékelést. Már ebből is látható, hogy a tanulók és a pedagógusok véleménye nem teljesen egyezik meg ezeken a területeken, melyet a független kétmintás t-próbával végzett statisztikai elemzéseink is igazoltak. A pedagógusok minden tekintetben jobbra értékelik az iskolájukat és saját felkészültségüket, mely különösen a 8 pedagóguskompetenciát tömörítő index értéke és a tanulóközpontúság megítélése kapcsán érhető tetten (4. táblázat).

4. táblázat. A tanulók és pedagógusok oktatási célokkal, elvárásokkal és a pedagógusok felkészültségével kapcsolatos véleményei (0-100 fokú skálák átlagértéke és szórása)*

\begin{tabular}{|c|c|c|c|c|}
\hline Kérdéskör & Minta & $\mathbf{N}$ & Átlag & Szórás \\
\hline \multicolumn{5}{|c|}{ Oktatási célok, elvárások } \\
\hline \multirow{2}{*}{ Kimenet-központúság (tanulási kimenetek) } & tanulói & 1815 & 74,3 & 22,73 \\
\hline & pedagógus & 1096 & 77,7 & 16,47 \\
\hline \multirow{2}{*}{ Magas színvonal és elvárások } & tanulói & 1813 & 70,0 & 20,36 \\
\hline & pedagógus & 1097 & 75,1 & 16,04 \\
\hline \multirow{2}{*}{$\begin{array}{l}\text { Tanuló-központúság (tanulókra fordított } \\
\text { figyelem) }\end{array}$} & tanulói & 1804 & 69,2 & 22,18 \\
\hline & pedagógus & 1112 & 79,5 & 15,72 \\
\hline \multicolumn{5}{|c|}{ Pedagóguskompetenciák } \\
\hline \multirow{2}{*}{ Pedagógusok felkészültsége } & tanulói & 1764 & 70,2 & 20,35 \\
\hline & pedagógus & 1094 & 82,5 & 13,39 \\
\hline \multirow{2}{*}{ Pedagógusok digitális kompetenciája } & tanulói & 1860 & 67,1 & 29,42 \\
\hline & pedagógus & 1112 & 73,5 & 21,44 \\
\hline
\end{tabular}

Megjegyzés: *A tanulók és a pedagógusok közötti különbségek vizsgálata független kétmintás t-próba alapján: $\mathrm{p}<0,001$. (A kérdéskörök a tanulók értékítélete alapján csökkenő sorrendben jelennek meg.) 
A célok és elvárások, valamint a pedagóguskompetenciák dimenziói a tanulók és a pedagógusok körében is összefüggnek, ugyanakkor annak mértéke föként a pedagóguskompetenciák esetében eltéréseket mutat a két csoportban. Míg a célok és elvárások dimenziói között a tanulók és a pedagógusok esetében is erős összefüggések tapasztalhatók $(\mathrm{r}>0,55 ; \mathrm{p}<001)$, addig a pedagóguskompetenciák megítélése a tanulók körében lényegesen erősebben függ össze az iskolájukról, annak céljairól, elvárásairól alkotott véleményeikkel, mint ami a pedagógusok esetében látható (5. táblázat). Ez arra utal, hogy a pedagógusok - a tanulókkal ellentétben - a saját tevékenységük megítélését nem feltétlenül kötik össze iskolájuk oktatási színvonalával, elvárásaival és jellemző gyakorlatával.

A célok és elvárások, valamint a pedagóguskompetenciák dimenziói a tanulók és a pedagógusok körében is összefüggnek, ugyanakkor annak mértéke fóként a pedagóguskompetenciák esetében eltéréseket mutat a két csoportban. Míg a célok és elvárások dimenziói között a tanulók és a pedagógusok esetében is erôs összefüggések tapasztalhatók ( $r>0,55 ; p<001)$, addig a pedagóguskompetenciák megitélése a tanulók körében lényegesen erốsebben függ össze az iskolájukról, annak céljairól, elvárásairól alkotott véleményeikkel, mint ami a pedagógusok esetében látható (5. táblázat).

5. táblázat. A célok, elvárások dimenziói és a pedagóguskompetenciák közötti korrelációk*

\begin{tabular}{|l|c|c|c|c|c|}
\hline & \multicolumn{1}{|c|}{$\begin{array}{c}\text { Kimenet- } \\
\text { központúság }\end{array}$} & $\begin{array}{c}\text { Magas } \\
\text { színvonal, } \\
\text { elvárások }\end{array}$ & $\begin{array}{c}\text { Tanuló-köz- } \\
\text { pontúság }\end{array}$ & $\begin{array}{c}\text { Pedagógu- } \\
\text { sok felké- } \\
\text { szültsége }\end{array}$ & $\begin{array}{c}\text { Pedagógu- } \\
\text { sok digitális } \\
\text { kompeten- } \\
\text { ciája }\end{array}$ \\
\hline \multicolumn{5}{|c|}{ Tanulói } \\
\hline $\begin{array}{l}\text { Kimenet- } \\
\text { központúság }\end{array}$ & 1 & 0,547 & 0,638 & 0,683 & 0,400 \\
\hline $\begin{array}{l}\text { Magas színvonal és } \\
\text { elvárások }\end{array}$ & 0,547 & 1 & 0,614 & 0,546 & 0,345 \\
\hline Tanuló-központúság & 0,638 & 0,614 & 1 & 0,655 & 0,380 \\
\hline $\begin{array}{l}\text { Pedagógusok } \\
\text { felkészültsége }\end{array}$ & 0,683 & 0,546 & 0,655 & 1 & 0,550 \\
\hline $\begin{array}{l}\text { Pedagógusok } \\
\text { digitális } \\
\text { kompetenciája }\end{array}$ & 0,400 & 0,345 & 0,380 & 0,550 & 1 \\
\hline
\end{tabular}




\begin{tabular}{|l|c|c|c|c|c|}
\hline \multicolumn{7}{|c|}{$\begin{array}{c}\text { Kimenet- } \\
\text { központúság }\end{array}$} & $\begin{array}{c}\text { Magas } \\
\text { színvonal, } \\
\text { elvárások }\end{array}$ & $\begin{array}{c}\text { Tanuló-köz- } \\
\text { pontúság }\end{array}$ & $\begin{array}{c}\text { Pedagógu- } \\
\text { sok felké- } \\
\text { szültsége }\end{array}$ & $\begin{array}{c}\text { Pedagógu- } \\
\text { sok digitális } \\
\text { kompeten- } \\
\text { ciája }\end{array}$ \\
\cline { 2 - 7 } & \multicolumn{7}{|c|}{ Pedagógus } \\
\hline $\begin{array}{l}\text { Kimenet- } \\
\text { központúság }\end{array}$ & 1 & 0,622 & 0,683 & 0,355 & 0,262 \\
\hline $\begin{array}{l}\text { Magas színvonal és } \\
\text { elvárások }\end{array}$ & 0,622 & 1 & 0,548 & 0,297 & 0,226 \\
\hline Tanuló-központúság & 0,683 & 0,548 & 1 & 0,345 & 0,219 \\
\hline $\begin{array}{l}\text { Pedagógusok } \\
\text { felkészültsége }\end{array}$ & 0,355 & 0,297 & 0,345 & 1 & 0,380 \\
\hline $\begin{array}{l}\text { Pedagógusok } \\
\text { digitális } \\
\text { kompetenciája }\end{array}$ & 0,262 & 0,226 & 0,219 & 0,380 & 1 \\
\hline
\end{tabular}

Megjegyzés: *Pearson-féle korrelációs együtthatókhoz tartozó szignifikanciaérték minden esetben p $<0,001$. (A táblázatban a legalább közepesen erős, jelentős kapcsolatot mutató korrelációs együtthatókat $-r>0,4-$ dőlten jelöltük.)

\section{Élettel való elégedettség és bizalom}

Az iskolai kötődést és légkörérzetet befolyásolhatja az iskola szereplőinek elégedettségérzete és bizalmi szintje is. Az elégedettség kapcsán az élettel való elégedettséget mértük fel a 11 fokozatú Cantril-létra segítségével (Cantril, 1965), míg a bizalom kapcsán az önmagukba, illetve a jövőbe vetett bizalmuk mértékét tártuk fel.

A tanulók körében az önbizalom mértéke a legmagasabb, s a szubjektív elégedettségérzet a legalacsonyabb, hozzátéve, hogy a vizsgált területeket mérő indexértékek között nem tapasztalható jelentősnek mondható különbség. A pedagógusok esetében szintén az önbizalom mértéke emelkedik ki, ugyanakkor ettől érezhetően elmarad a jövőbe vetett bizalom és az élettel való általános elégedettség szintje. Mind a bizalmi szint, mind a szubjektív elégedettségérzet statisztikailag szignifikáns különbséget mutat a tanulók és a pedagógusok között - az önbizalom kivételével a tanulók javára -, a legnagyobb különbség a jövőbe vetett bizalom megítélése kapcsán látható (6. táblázat).

6. táblázat. A tanulók és pedagógusok szubjektiv elégedettségérzete és bizalmi szintje (0-100 fokú skálák átlagértéke és szórása)*

\begin{tabular}{|l|l|c|c|c|}
\hline \multicolumn{1}{|c|}{ Kérdéskör } & \multicolumn{1}{|c|}{ Minta } & $\mathbf{N}$ & Átlag & Szórás \\
\hline \multirow{2}{*}{ Önmagába vetett bizalom** } & tanulói & 1711 & 82,0 & 28,17 \\
\cline { 2 - 5 } & pedagógus & 1052 & 84,2 & 17,82 \\
\hline \multirow{2}{*}{ Jövőbe vetett bizalom* } & tanulói & 1705 & 78,7 & 26,53 \\
\cline { 2 - 5 } & pedagógus & 1051 & 68,6 & 22,97 \\
\hline \multirow{2}{*}{ Élettel való elégedettség* } & tanulói & 1782 & 75,9 & 20,17 \\
\cline { 2 - 5 } & pedagógus & 1050 & 69,9 & 16,43 \\
\hline
\end{tabular}

Megjegyzés: A tanulók és a pedagógusok közötti különbségek vizsgálata független kétmintás t-próba alapján: ${ }^{*} \mathrm{p}<0,001,{ }^{* *} \mathrm{p}<0,05$. (A kérdéskörök a tanulók értékítélete alapján csökkenő sorrendben jelennek meg.) 
Érdekes megfigyelni, hogy a tanulók körében az élettel való elégedettség érzete kisebb mértékben függ össze a bizalommal, s inkább a két bizalmi dimenzió (önmagukba, illetve jövőbe vetett bizalom) jár együtt erőteljesebben. A pedagógusok esetében viszont nem a két bizalmi dimenzió, hanem a szubjektív elégedettségérzet és a jövőbe vetett bizalom szintje között mérhető nagyobb összefüggés (7. táblázat).

7. táblázat. A bizalmi dimenziók és a szubjektiv elégedettségérzet közötti korrelációk*

\begin{tabular}{|l|c|c|c|}
\hline & $\begin{array}{c}\text { Önmagába vetett } \\
\text { bizalom }\end{array}$ & $\begin{array}{c}\text { Jövöbe vetett } \\
\text { bizalom }\end{array}$ & $\begin{array}{c}\text { Élettel való } \\
\text { elégedettség }\end{array}$ \\
\hline \multicolumn{4}{|c|}{ Tanulói } \\
\hline Önmagába vetett bizalom & 1 & 0,534 & 0,266 \\
\hline Jövőbe vetett bizalom & 0,534 & 1 & 0,236 \\
\hline Élettel való elégedettség & 0,266 & 0,236 & 1 \\
\hline \multicolumn{4}{|c|}{ Pedagógus } \\
\hline Önmagába vetett bizalom & 1 & 0,389 & 0,208 \\
\hline Jövőbe vetett bizalom & 0,389 & 1 & 0,452 \\
\hline Élettel való elégedettség & 0,208 & 0,452 & 1 \\
\hline
\end{tabular}

Megjegyzés: *Pearson-féle korrelációs együtthatókhoz tartozó szignifikanciaérték minden esetben p $<0,001$. (A táblázatban a legalább közepesen erős, jelentős kapcsolatot mutató korrelációs együtthatókat - r $>0,4-$ dőlten jelöltük.)

\section{Az iskolai légkörérzetet meghatározó dimenziók}

Mivel a Pearson-féle korrelációs együtthatók alapján valamennyi vizsgált dimenzióval az iskolai légkörérzetet jelző index mutatja a legszorosabb kapcsolatot, ezért a továbbiakban azt vizsgáljuk, hogy az iskolai kötődés, az oktatási célok, elvárások és pedagóguskompetenciák, valamint az élettel való elégedettség és a bizalom dimenziói közül melyek azok, amelyek leginkább meghatározzák a tanulók, illetve a pedagógusok által észlelt iskolai légkört. Az elemzést a tanulók, illetve a pedagógusok körében stepwise-módszerrel futtatott lineáris regressziók segítségével végeztük el.

A tanulók körében 6 lépésben épített szignifikáns $(\mathrm{p}<0,001)$ lineáris modell a tanulók iskolai légkörérzete varianciájának több mint hattizedét magyarázza (korrigált $\left.\mathrm{R}^{2}=0,621\right)$. A modellben maradó 6 változó értékében bekövetkező pozitív irányú elmozdulás pozitív irányba befolyásolja a légkörérzetet. A tanulók légkörérzetében a legerősebb szerepet a pedagógusok felkészültségének megítélése $(\beta=0,415)$, valamint a tantárgyi-tanulási kötődés játssza $(\beta=0,251)$. Kiemelendő még az interperszonális kötődés szerepe is $(\beta=0,132)$. A többi tényező (tanulási kimenetek, önbizalom mértéke, tanulókra fordított figyelem) szerepe kisebb és lényegében ugyanolyan mértékü (8. táblázat). 
8. táblázat. A tanulói légkörérzet becslésére létrehozott regressziós modell összefoglalása

\begin{tabular}{|l|c|c|c|c|c|}
\hline & \multicolumn{2}{|c|}{$\begin{array}{c}\text { Standardizálatlan } \\
\text { paraméterek }\end{array}$} & $\begin{array}{c}\text { Standardizált } \\
\text { paraméterek }\end{array}$ & \multirow{2}{*}{ t } & \multirow{2}{*}{ Sig. } \\
\cline { 2 - 6 } & $\mathbf{B}$ & Std. hiba & Beta & & \\
\hline Konstans & $-5,162$ & 1,752 & & $-2,946$ & 0,003 \\
\hline Pedagógusok felkészültsége & 0,411 & 0,027 & 0,415 & 15,038 & 0,000 \\
\hline Tantárgyi-tanulási kötődés & 0,239 & 0,018 & 0,277 & 13,222 & 0,000 \\
\hline Interperszonális kötődés & 0,131 & 0,019 & 0,132 & 6,774 & 0,000 \\
\hline Kimenet-központúság & 0,070 & 0,023 & 0,078 & 3,047 & 0,002 \\
\hline Önmagába vetett bizalom & 0,054 & 0,013 & 0,076 & 4,271 & 0,000 \\
\hline Tanuló-központúság & 0,068 & 0,022 & 0,075 & 3,044 & 0,002 \\
\hline
\end{tabular}

Megjegyzés: A modellbe való belépési küszöb: $\mathrm{p}<0,01$, modellben maradási küszöb: $\mathrm{p}<0,05$. Függő változó: a tanuló légkörérzete.

A pedagógusok esetében 5 lépésben jött létre szignifikáns $(\mathrm{p}<0,001)$ lineáris modell, amely a pedagógusok iskolai légkörérzete varianciájának több mint felét magyarázza (korrigált $\left.\mathrm{R}^{2}=0,524\right)$. A tanulói légkörérzet magyarázatára épített modellhez hasonlóan ebben a modellben is a bennmaradó változók pozitív irányba befolyásolják a pedagógusok légkörérzetet. A pedagógusok légkörérzetében a legerősebb szerep az interperszonális kötődésé $(\beta=0,362)$, de nagy szerep jut az iskola tanuló-központúságának is $(\beta=0,290)$. A többi tényező (kimenetközpontú iskola, tantárgyi-tanítási kötődés, iskola magas színvonalú oktatása és elvárásai) szerepe alacsonyabb és kiegyenlítetten alakul (9. táblázat).

9. táblázat. A pedagógus légkörérzet becslésére létrehozott regressziós modell összefoglalása

\begin{tabular}{|l|c|c|c|c|c|}
\hline & \multicolumn{2}{|c|}{$\begin{array}{c}\text { Standardizálatlan } \\
\text { paraméterek }\end{array}$} & $\begin{array}{c}\text { Standardizált } \\
\text { paraméterek }\end{array}$ & \multirow{2}{*}{ t } & \multirow{2}{*}{ Sig. } \\
\cline { 2 - 5 } & $\mathbf{B}$ & Std. hiba & Beta & & \\
\hline Konstans & $-8,158$ & 2,591 & & $-3,148$ & 0,002 \\
\hline Interperszonális kötődés & 0,362 & 0,029 & 0,362 & 12,686 & 0,000 \\
\hline Tanuló-központúság & 0,320 & 0,035 & 0,290 & 9,046 & 0,000 \\
\hline Kimenet-központúság & 0,124 & 0,036 & 0,118 & 3,490 & 0,001 \\
\hline Tantárgyi-tanítási kötödés & 0,092 & 0,023 & 0,110 & 4,000 & 0,000 \\
\hline Magas színvonal és elvárások & 0,115 & 0,032 & 0,106 & 3,545 & 0,000 \\
\hline
\end{tabular}

Megjegyzés: A modellbe való belépési küszöb: $\mathrm{p}<0,01$, modellben maradási küszöb: $\mathrm{p}<0,05$. Függő változó: a pedagógus légkörérzete.

Látható tehát, hogy mind a tanulók, mind a pedagógusok légkörérzetében nagy szerepe van a tantárgyi-tanulási/tanítási kötődésnek, az interperszonális kötődésnek, valamint az iskolában észlelt kimenet- és tanuló-központúságnak. A tanulók légkörérzetét ezen felül az iskola pedagógusainak diákok által vélelmezett felkészültsége, valamint a tanulók önmagukba vetett bizalma is befolyásolja, míg a pedagógusok légkörérzetét az iskola pedagógusok által érzékelt magas oktatási színvonala és elvárásai. 


\section{Összegzés}

Tanulmányunkban olyan területekkel kapcsolatos tanulói és pedagógusvéleményeket vetettünk össze, amelyek befolyásolhatják az iskolai lemorzsolódás mértékének alakulását. Így egy, az iskolai lemorzsolódás hazai elemzését célzó komplex kutatás keretében 2018 őszén végzett online tanulói és pedagógus kérdőíves adatfelvételre alapozva vizsgáltuk a tanulók és a pedagógusok által érzékelt iskolai légkör, elkötelezödés, közösségi bevonódás és kötődés szintjében tapasztalt különbségeket, s elemeztük az iskolai célok és elvárások megítélésében, a pedagóguskompetenciák értékelésében, valamint az élettel való elégedettség és bizalom szintjében tapasztalható eltéréseket is.

Eredményeink szerint mind a tanulók, mind a pedagógusok leginkább társaikhoz kötődnek (diák a diákhoz, tanár a tanárhoz) az iskolákban, vagyis az osztályközösségbe, illetve tantestületbe való bevonódásuk és az interperszonális kötődésük a legmagasabb. Általánosságban az is kijelenthetö, hogy a tanulók közösségi bevonódása, iskolai kötödése és légkörérzete jelentősen alacsonyabb, mint a pedagógusok közösségi bevonódása, munka és szervezet iránti elköteleződése, illetve légkörérzete. Elmondható továbbá, hogy a pedagógusok minden tekintetben jobbra értékelik iskolájukat és önmaguk tudását is, mint a tanulók, mely különösen a 8 pedagóguskompetenciát tömörítő index értéke - mely nem tartalmazza a digitális kompetenciát - és az iskola tanulóközpontúságának megítélése kapcsán érhető tetten.

A tanulók és a pedagógusok körében is kiemelkedő az önmagukba vetett bizalom szintje, ugyanakkor föként a pedagógusok esetében ettől lényegesen elmarad a jövőbe vetett bizalom és az élettel való általános elégedettség szintje. A tanulók esetében a szubjektív elégedettségérzet kisebb mértékben függ össze a bizalommal, inkább az önmagukba és a jövőbe vetett bizalom jár együtt. Ezzel szemben a pedagógusok körében a szubjektív elégedettségérzet és a jövőbe vetett bizalom szintje között tapasztalható erösebb összefüggés.

Elemzéseink alapján az iskolai légkörérzet mutat leginkább kapcsolatot az összes vizsgált dimenzióval, ezért megvizsgáltuk, mely dimenziók befolyásolják leginkább a tanulók, illetve a pedagógusok légkörérzetét. A tanulók és a pedagógusok légkörérzetére egyaránt nagy hatást gyakorol a tantárgyi-tanulási/tanítási kötődés, az interperszonális kötődés, valamint az iskolában észlelt kimenet- és tanuló-központúság mértéke. Ezen felül a tanulók körében az iskola pedagógusainak diákok által vélelmezett felkészültségének és
Eredményeink szerint mind a tanulók, mind a pedagógusok leginkább társaikhoz kötódnek (diák a diákhoz, tanár a tanárhoz) az iskolákban, vagyis az osztályközösségbe, illetve tantestületbe való bevonódásuk és az interperszonális kötódésük a legmagasabb. Általánosságban az is kijelenthetö, hogy a tanulók közösségi bevonódása, isko-

lai kötôdése és légkörérzete pedagógusok közösségi bevonódása, munka és szervezet iránti elkötelezódése, illetve légkörérzete. Elmondható továbbá, hogy a pedagógusok minden tekintetben jobbra értékelik iskolájukat és önmaguk tudását is, mint a

tanulók, mely különösen a 8 pedagóguskompetenciát tömörítô index értéke - mely nem tartalmazza a digitális kompetenciát - és az iskola tanulóközpontúságának megitélése kapcsán érhetô tetten. jelentösen alacsonyabb, mint a 
a diákok önmagukba vetett bizalmának, míg a pedagógusok körében az iskola pedagógusok által érzékelt magas oktatási színvonalának és elvárásainak van még meghatározó szerepe.

\section{Köszönetnyilvánítás, támogatás}

A köznevelés módszertani megújítása a végzettség nélküli iskolaelhagyás csökkentése céljából a köznevelési intézményekben címü pályázati program az EFOP-3.1.2-16-201600001 azonosítószámú támogatással valósult meg.

\section{Irodalom}

Allen, K.-A. \& Bowles, T. (2012). Belonging as a Guiding Principle in the Education of Adolescents. Australian Journal of Educational \& Developmental Psychology, 12, 108-119.

Allen, K.-A., \& Kern, M. L. (2017). Springer briefs in psychology. School belonging in adolescents: Theory, research and practice. Springer Science + Business Media. DOI: 10.1007/978-981-10-5996-4

Allen, K.-A., Kern, M. L., Vella-Brodrick, D., Hattie, J. \& Waters, L. (2018). What Schools Need to Know About Fostering School Belonging: a Meta-analysis. Educational Psychology Review, 30(1), 1-34. DOI: 10.1007/s10648-016-9389-8

Anari, N. N. (2012). Teachers: Emotional intelligence, job satisfaction, and organizational commitment. Journal of Workplace Learning, 24(4), 256-269. DOI: $10.1108 / 13665621211223379$

Anderson, C. S. (1982). The Search for School Climate: A Review of the Research. Review of Educational Research, 52(3), 368-420. DOI: $10.3102 / 00346543052003368$

Appleton, J. J., Christenson, S. L. \& Furlong, M. J. (2008). Student engagement with school: Critical conceptual and methodological issues of the construct. Psychology in the Schools, 45(5), 369-386. DOI: $10.1002 /$ pits.20303

Bacskai Katinka (2007). Iskolai légkörvizsgálat nyolc debreceni gimnáziumban. Educatio, 16(2), 323-330.

Bacskai Katinka (2015). Iskolák a társadalom peremén. Alacsony státusú diákokat tanitó eredményes tanárok. Szeged: Belvedere Meridionale. DOI: 10.14232/belvbook.2015.58513

Balázs László (2014). Iskolai klíma hatása a tanulói teljesítményre. In Balázs László, H. Tomesz Tímea \& H. Varga Gyula (szerk.), A kommunikáció(s készségfejlesztés) tantárgyközi szerepe, lehetőségei. Budapest: Hungarovox Kiadó. 38-54.

Bogler, R. \& Somech, A. (2004). Influence of Teacher Empowerment on Teachers Organizational Commitment, Professional Commitment and Organizational Citizenship Behavior in Schools. Teaching and
Teacher Education, 20, 277-289. DOI: 10.1016/j. tate.2004.02.003

Bond, L., Butler, H., Thomas, L., Carlin, J., Glover, S., Bowes, G. \& Patton, G. (2007). Social and School Connectedness in Early Secondary School as Predictors of Late Teenage Substance Use, Mental Health and Academic Outcomes. Journal of Adolescent Health, 40(4), 9-18. DOI: 10.1016/j.jadohealth.2006.10.013

Bourdieu, P. (1997). Gazdasági tőke, kulturális tőke, társadalmi tőke. In Angelusz Róbert (szerk.), A társadalmi rétegzödés komponensei. Budapest: Új Mandátum Kiadó. 156-177.

Brand, S., Felner, R., Shim, M., Seitsinger, A. \& Dumas, T. (2003). Middle school improvement and reform: Development and validation of a school-level assessment of climate, cultural pluralism, and school safety. Journal of Educational Psychology, 95(3), 570-588. DOI: 10.1037/0022-0663.95.3.570

Brookover, W. B., Schweitzer, J. H., Schneider, J. M., Beady, C. H., Flood, P. K., Wisenbaker, J. M. (1978). Elementary School Social Climate and School Achievement. American Educational Research Journal, 15(2), 301-318. DOI: 10.3102/00028312015002301

Bryk, A. S. \& Schneider, B. (2002). Trust in Schools: A Core Resource for Improvement. New York: Russell Sage Foundation.

Cantril, H. (1965). The Pattern of Human Concern. Rutgers University Press.

Catalano, R. F., Haggerty, K. P., Oesterle, S., Fleming, C. B. \& Hawkins, J. D. (2004). The Importance of Bonding to School forHealthy Development: Findings from the Social Development Research Group. Journal of School Health, 74(7), 252-261. DOI: 10.1111/j.1746-1561.2004.tb08281.x

Cohen, J. (2012). School Climate and Culture Improvement: A Prosocial Strategy That Recognizes, Educates, and Supports the Whole Child and the Whole School Community. In Brown, P. M., Corrigan, M. W. \& Higgins-D'Alessandro, A. (szerk.), 
Handbook of prosocial education. Lanham, MD: Rowman \& Littlefield Publishers. 227-252.

Cohen, J., McCabe, L., Michelli, N. M. \& Pickeral, T. (2009). School climate: Research, Policy, Practice, and Teacher Education. Teachers College Record, 111(1), 180-213.

Coleman, J. S. (1988). Social Capital in the Creation of Human Capital. American Journal of Sociology, 94, 95-120. DOI: $10.1086 / 228943$

Collins, T. N. \& Parsons, K. A. (2010). School Climate and Student Outcomes. Journal of Cross-Disciplinary Perspectives in Education, 3(1), 34-39.

Creemers, B. P. M. \& Reezigt, G. J. (1999). The Role of School and Classroom Climate in Elementary School Learning Environments. In Freiberg, J. H. (szerk.), School Climate. Measuring, Improving and Sustaining Healthy Learning Environments. London: Falmer Press. 30-48.

Davis, K. (2012). Friendship 2.0: Adolescents' experiences of belonging and self-disclosure online. Journal of Adolescence, 35(6), 1527-1536. DOI: 10.1016/j.adolescence.2012.02.013

Day, C. \& Gu, Q. (2014). Resilient Teachers, Resilient Schools: Building and Sustaining Quality in Testing Times (Teacher Quality and School Development). London: Routledge. DOI: 10.4324/9780203578490

Dronkers, J. \& Róbert, P. (2003). The Effectiveness of Public and Private Schools from a Comparative Perspective. EUI Working Paper SPS No. 2003/13. San Domenico: European University Institute. http:// cadmus.eui.eu/handle/1814/1360 Utolsó letöltés: 2017. 03. 10.

Fehérvári Anikó, Magyar Éva \& Széll Krisztián (2020). A tanulói lemorzsolódás empirikus vizsgálata - elméleti és módszertani keretek. Iskolakultúra, 30(8), 3-20.

Fényes Hajnalka (2008). Kontextuális hatások a középiskolások eredményességére. Szociológiai Szemle, 18(3), 3-31.

Fényes Hajnalka \& Pusztai Gabriella (2004). A kulturális és a társadalmi tőke kontextuális hatásai az iskolában. Statisztikai Szemle, 82(6-7), 567-582.

Firestone, W. A. \& Pennell, J. R. (1993). Teacher commitment, working conditions, and differential incentive policies. Review of Educational Research, 63(4), 489-525. DOI: 10.3102/00346543063004489

Fleming, C., Haggerty, K., Catalano, R., Harachi, T., Mazza, J. \& Gruman, D. (2005). Do Social and Behavioral Characteristics Targeted by Preventive Interventions Predict Standardized Test Scores and Grades? Journal of School Health, 75(9), 342-349. DOI: $10.1111 / \mathrm{j} .1746-1561.2005 .00048 . x$

Fredricks, J. A., Blumenfeld, P. C. \& Paris, A. H. (2004). School Engagement: Potential of the Concept, State of the Evidence. Review of Educational Research, 74(1), 59-109. DOI: 10.3102/00346543074001059
Freiberg, J. H. (1999, szerk.). School Climate: Measuring, Improving and Sustanining Healthy Learning Environments. London: Falmer Press. DOI: $10.4324 / 9780203983980$

Frey, A., Ruchkin, V., Martin, A. \& Schwab-Stone, M. (2008). Adolescents in Transition: School and Family Characteristics in The Development of Violent Behaviors Entering High School. Child Psychiatry Human Development, 40(1), 1-13. DOI: 10.1007/ s10578-008-0105-x

Frydenberg, E., Care, E., Freeman, E. \& Chan, E. (2009). Interrelationships between coping, school connectedness and wellbeing. Australian Journal of Education, 53(3), 261-276. DOI: 10.1177/000494410905300305

Gottfredson, D. C. (2001). Schools and delinquency. Cambridge: Cambridge University Press.

Green, J., Liem, G. A. D., Martin, A. J., Colmar, S., Marsh, H. W. \& McInerney, D. (2012). Academic motivation, self-concept, engagement, and performance in high school: Key processes from a longitudinal perspective. Journal of Adolescence, 35(5), 1111-1122. DOI: 10.1016/j.adolescence.2012.02.016

Griffith, J. (1995). An Empirical Examination of a Model of Social Climate in Elementary Schools. Basic and Applied Social Psychology, 17(1-2), 97-117. DOI: 10.1080/01973533.1995.9646134

Griffiths, A.-J., Sharkey, J. D. \& Furlong, M. J. (2009). Student engagement and positive school adaptation. In Gilman, R., Huebner, E. S. \& Furlong, M. J. (szerk.), Handbook of positive psychology in schools. Routledge/Taylor \& Francis Group. 197-211.

Halpin, A. W. \& Croft, D. B. (1963). The Organisational Climate of Schools. Chicago: Midwest Administration Center, University of Chicago.

Hakanen, J. J., Bakker, A. B. \& Schaufeli, W. B. (2006). Burnout and work engagement among teachers. Journal of School Psychology, 43(6), 495-513. DOI: $10.1016 /$ j.jsp.2005.11.001

Hargreaves, A. \& Fullan, M. (2012). Professional Capital: Transforming Teaching in Every School. New York: Teachers College Press.

Hoy, W. K. \& Miskel, C. G. (2013). Educational Adminisitration: Theory, Research, and Practice. 9. kiadás. New York: McGraw-Hill.

Jámbori Szilvia, Kőrössy Judit \& Szabó Éva (2019). A reziliencia, az énhatékonyság és az iskolai kötődés szerepe a szándékos önszabályozás folyamatában. Magyar Pedagógia, 119(1), 75-94. DOI: 10.17670/ mped.2019.1.75

Jenkins, P. H. (1997). School Delinquency and the School Social Bond. Journal of Research in Crime and Delinquency, 34(3), 337-367. DOI: 10.1177/0022427897034003003

Jetten, J., Haslam, S. A., Cruwys, T., Greenaway, K., Haslam, C. \& Steffens, N. K. (2017). Advancing the Social Identity Approach to Health and Well-being: 
Progressing The Social Cure Research Agenda. European Journal of Social Psychology, 47(7), 789-802. DOI: 10.1002/ejsp.2333

Juvonen, J., Espinoza, G. \& Knifsend, C. (2012). The Role of Peer Relationships in Student Academic and Extracurricular Engagement. In Christenson, S. L., Wylie, C. \& Reschly, A. L. (szerk.), Handbook of Research on Student Engagement, Springer Science + Business Media, 387-401. DOI: 10.1007/978-14614-2018-7_18

Klassen, R. M., Aldhafri, S., Mansfield, C. F., Purwanto, E., Siu, A. F. Y., Wong, M. W. \& Woods-Mcconney, A. (2012). Teachers engagement at work: An international validation study. Journal of Experimental Education, 80(4), 317-337. DOI: 10.1080/00220973.2012.678409

Kocsis Mihály (2002). Tanárok véleménye a pályáról és a képzésről. Iskolakultúra, 12(5), 66-78.

Kun Ágota \& Szabó Anett (2017). Boldogság tényezők a pedagógusok munkájában. Magyar Pszichológiai Szemle, 72(3), 281-310. DOI: 10.1556/0016.2017.001

Lannert Judit (2006). Az iskolaeredményességi kutatások nemzetközi tapasztalatai. In Lannert Judit \& Nagy Mária (szerk.), Eredményes iskola: Adatok és esetek. Budapest: Országos Közoktatási Intézet. $17-42$.

Leana, C. (2010). Social Capital: The Collective Component of Teaching Quality. Voices in Urban Education, 27, 16-23.

Leana, C. \& Pil, F. K. (2006). Social capital and organizational performance: Evidence from urban public schools. Organization Science, 17(3), 353366. DOI: 10.1287/orsc.1060.0191

Libbey, H. P. (2004). Measuring student relationships to school: Attachment, bonding, connectedness, and engagement. Journal of School Health, 74, 274-283. DOI: $10.1111 / \mathrm{j} .1746-1561.2004 . t b 08284 . \mathrm{x}$

Lombardi, E., Traficante, D., Bettoni, R., Offredi, I., Giorgetti, M. \& Vernice, M. (2019). The Impact of School Climate on Well-Being Experience and School Engagement: A Study With High-School Students. Frontiers in Psychology, 10(2482), 1-11. DOI: 10.3389/fpsyg.2019.02482

Louis, K. S. \& Smith, B. (1992). Cultivating teacher engagement: Breaking the iron law of social class. In Newmann, F. (szerk.), Student engagement and achievement in American secondary schools. New York: Teachers College Press. 119-152.

Lyche, C. S (2010). Taking on the Completion Challenge a Literature Review on Policies to Prevent Dropout and Early School Leaving. OECD Education Working Paper No. 53. Paris: OECD publication. DOI: $10.1787 / 5 \mathrm{~km} 4 \mathrm{~m} 2 \mathrm{t} 59 \mathrm{cmr}-\mathrm{en}$

McMahon, S. D., Wernsman, J. \& Rose, D. S. (2009). The Relation of Classroom Environment and School Belonging to Academic Self-Efficacy among Urban
Fourth- and Fifth-Grade Students. Elementary School Journal, 109(3), 267-281. DOI: 10.1086/592307

Mérida-López, S., Extremera, N. \& Rey, L. (2017). Contributions of Work-Related Stress and Emotional Intelligence to Teacher Engagement: Additive and Interactive Effects. International Journal of Environmental Research and Public Health, 14(10), 1156. DOI: 10.3390/ijerph14101156

Mihálka Mária \& Pikó Bettina (2018). Pedagógusok élettel való elégedettsége és összefüggése a kiégéssel, valamint a pszichoszomatikus egészség mutatóival. Mentálhigiéné és Pszichoszomatika, 19(2), 140-157. DOI: 10.1556/0406.19.2018.006

Moller, S., Mickelson, R. A., Stearns, E., Banerjee, N. \& Bottia, M. C. (2013). Collective Pedagogical Teacher Culture and Mathematics Achievement: Differences by Race, Ethnicity, and Socioeconomic Status. Sociology of Education, 86(2), 174-194. DOI: 10.1177/0038040712472911

Moody, J. \& Bearman, P. S. (1998). Shaping School Climate: Shool Context Adolescent Social Networks, and Attachnent to School. Kézirat.

Nagy Krisztina \& Zsolnai, Anikó (2016). Az iskolai kötődés vizsgálata a társas viszonyok aspektusából. In Tóth Péter \& Holik Ildikó (szerk.), Új kutatások a neveléstudományokban 2015. Budapest: ELTE Eötvös Kiadó. 53-61.

Newmann, F. M. (1981). Reducing Student Alienation in High Schools: Implications of Theory. Harvard Educational Review, 51, 546-564. DOI: 10.17763/haer.51.4.xj67887u8715t66t

Newmann, F. M. (1992). Student engagement and achievement in American secondary schools. New York: Teachers College Press.

Newmann, F. M., Wehlage, G. G. \& Lamborn, S. D. (1992). The significance and sources of student engagement. In Newmann, F. M. (szerk.), Student engagement and achievement in American secondary schools. New York: Teachers College Press. 11-30.

Oelsner, J., Lippold, M. A. \& Greenberg, M. T. (2011). Factors Influencing the Development of School Bonding Among Middle School Students. Journal of Early Adolescence, 31(3), 463-487. DOI: $10.1177 / 0272431610366244$

Oldfield, J., Humphrey, N. \& Hebron, J. (2016). The Role of Parental and Peer Attachment Relationships and School Connectedness In Predicting Adolescent Mental Health Outcomes. Child and Adolescent Mental Health, 21(1), 21-29. DOI: 10.1111/camh.12108

Paksi Borbála \& Schmidt Andrea (2006). Pedagógusok mentálhigiénés állapota. Különös tekintettel az iskolai értékátadást, egészségfejlesztést és problémakezelést befolyásoló dimenziókra. Új Pedagógiai Szemle, 56(6), 48-64.

Paksi Borbála, Veroszta Zsuzsanna, Schmidt Andrea, Magi Anna, Vörös András, Endrődi-Kovácsi Viktória 
\& Felvinczi Katalin (2015). Pedagógus - Pálya - Motiváció - Egy kutatás eredményei. Budapest: Oktatási Hivatal.

Papanastasiou, C. (2008). Factors Distinguishing Most and Least Effective Schools in Terms of Reading Achievement: A Residual Approach. Educational Research and Evaluation, 14(6), 539-549. DOI: $10.1080 / 13803610802576767$

Park, I. (2005). Teacher commitment and its effects on student achievement in American high schools. Educational Research and Evaluation, 11(5), 461485. DOI: $10.1080 / 13803610500146269$

Pickeral, T., Evans, L. A., Hughes, W. \& Hutchison, D. (2009). School Climate Guide for District Policymakers and Educational Leaders. New York, NY: Center for Social and Emotional Education.

Pino-James, N., Shernoff, D. J., Bressler, D. M., Larson, S. C. \& Sinha, S. (2019). Instructional Interventions That Support Student Engagement: An International Perspective. In Fredricks, J. A., Reschly, A. L. \& Christenson, S. L. (szerk.), Handbook of Student Engagement Interventions: Working with Disengaged Students. Academic Press Elsevier. 103-119. DOI: 10.1016/b978-0-12-813413-9.00008-5

Pusztai Gabriella (2004). Iskola és közösség. Felekezeti középiskolások az ezredfordulón. Budapest: Gondolat.

Pusztai Gabriella (2009). A társadalmi tóke és az iskola. Kapcsolati erőforrások hatása az iskolai pályafutásra. Budapest: Új Mandátum Könyvkiadó.

Pusztai Gabriella (2015). Az eredményesség kapcsolati beágyazottsági háttere. In Imre Anna (szerk.), Eredményesség és társadalmi beágyazottság. Budapest: Oktatáskutató és Fejlesztő Intézet. 23-36.

Rehbein, F. \& Baier, D. (2013). Family-, media-, and school-related risk factors of video game addiction. Journal of Media Psychology, 25(3), 118-128. DOI: 10.1027/1864-1105/a000093

Reschly, A. L. \& Christenson, S. L. (2012). Jingle, Jangle, and Conceptual Haziness: Evolution and Future Directions of the Engagement Construct. In Christenson, S. L., Wylie, C. \& Reschly, A. L. (szerk.), Handbook of Research on Student Engagement, Springer Science + Business Media. 3-19. DOI: 10.1007/978-1-4614-2018-7 1

Rumberger, R. W. \& Rotermund, S. (2012). The Relationship Between Engagement and High School Dropout. In Christenson, S. L., Wylie, C. \& Reschly, A. L. (szerk.), Handbook of Research on Student
Engagement, Springer Science + Business Media. 491-513. DOI: 10.1007/978-1-4614-2018-7_24

Sági Matild (2015, szerk.). A pedagógushivatás megerősitésének néhány aspektusa. Budapest: Oktatáskutató és Fejlesztő Intézet.

Schaufeli, W. B., Bakker, A. B. \& Salanova, M. (2006). The Measurement of Work Engagement With a Short Questionnaire: A Cross-National Study. Educational and Psychological Measurement, 66(4), 701-716. DOI: 10.1177/0013164405282471

Simbula, S., Guglielmi, D. \& Schaufeli, W. B. (2011). A three-wave study of job resources, self-efficacy, and work engagement among Italian schoolteachers. European Journal of Work and Organizational Psychology, 20(3), 285-304. DOI: 10.1080/13594320903513916

Smithers, A. G. \& Robinson, P. L. (2003). Factors affecting teachers' decisions to leave the profession. Research report. https://dera.ioe.ac.uk/4759/1/ RR430.pdf Utolsó letöltés: 2020. 05. 18.

Somech, A. \& Bogler, R. (2002). Antecedents and Consequences of Teacher Organizational and Professional Commitment. Educational Administration Quarterly, 38(4), 555-577. DOI: 10.1177/001316102237672

Szabó Éva \& Jagodics Balázs (2016). Erőforrások és követelmények: A tanári kiégés munkahelyi tényezőinek komplex vizsgálata. Iskolakultúra, 26(11), 3-15. DOI: 10.17543/iskkult.2016.11.3

Szabó Éva \& Virányi Barbara (2011). Az iskolai kötődések jelentősége és vizsgálata. Magyar Pedagógia, 111(2), 111-125.

Szabó Károly (2000). A tanítási klíma mérése. $U_{j}$ Pedagógiai Szemle, 50(3), 61-71.

Szabó Lilla (2018). Az iskolai kötődés és a lemorzsolódás összefüggései. Educatio, 27(4), 692-699. DOI: 10.1556/2063.27.2018.4.11

Széll Krisztián (2018). Iskolai légkör és eredményesség: fókuszban a reziliens és a veszélyeztetett iskolák. Szeged: Belvedere Meridionale. DOI: 10.14232/belvbook.2018.58536

Széll Krisztián, Fehérvári Anikó \& Paksi Borbála (2018). Pedagógusok, iskola, bizalom - egy mozgalmas évtized változásai. Educatio, 27(4), 581-602. DOI: 10.1556/2063.27.2018.4.4

Thapa, A., Cohen, J., Guffey, S. \& Higgins-D’Alessandro, A. (2013). A Review of School Climate Research. Review of Educational Research, 83(3), 357-385. DOI: 10.3102/0034654313483907 


\title{
Jegyzetek
}

${ }^{1}$ A közösségi bevonódást az alábbi kérdéssel mértük (vö. Rehbein és mtsai, 2013). Tanulók: „Ha a kis kör ábrázol Téged, a nagy kör pedig az osztályodat, kérünk, jelöld meg, hogy az alábbi ábrák közül melyik mutatja a legjobban, hogy mennyire érzed Magad az osztályközösség részének!” Pedagógusok: „Ha a kis kör ábrázolja Önt, a nagy kör pedig a tantestületet, kérjük, jelölje meg, hogy az alábbi ábrák közül melyik mutatja a legjobban, hogy mennyire érzi Magát a tantestület részének!’ Válaszlehetőségek (a pedagógus kérdőíven az osztály helyett tantestület szerepelt):

1.
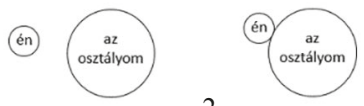

3.

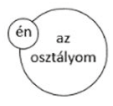

4.

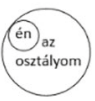

5

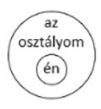
teljesen bevonódott.

${ }^{2}$ https://net.jogtar.hu/jogszabaly?docid=a1300008.emm

\begin{abstract}
Absztrakt
A tanulmány többféle nézőpont elemzésére fókuszál, a tanulói és pedagógus vélemények összevetésével. Az írás alapvetően az iskolai elköteleződés, bevonódás, kötődés, légkör jellemzőivel foglalkozik, ugyanakkor kitér a kérdéskörhöz szorosan kapcsolódó egyéb területek összevetésére is, így vizsgálja a közösségi bevonódás mértékében, az iskolai célok és elvárások megítélésében, a pedagóguskompetenciák értékelésében, valamint az élettel való elégedettség és bizalom szintjében a megkérdezett tanulók és pedagógusok véleményei között tapasztalható eltéréseket. A tanulmány első része a tanulók iskolai kötődésével, a pedagógusok munka és szervezet iránti elköteleződésével, valamint az iskolai klímával kapcsolatos értelmezési lehetőségeket járja körül, s kitér a témában eddig született legfontosabb empirikus kutatási eredmények ismertetésére is. A második rész ezen témakörökre fókuszálva egy, az iskolai lemorzsolódás hazai elemzését célzó komplex kutatás keretében 2018 őszén végzett tanulói és pedagógus kérdőíves adatfelvételre alapozva elemzi a tanulók ( $\mathrm{n}=1953)$ és a pedagógusok $(n=1136)$ véleménye közötti különbségeket.
\end{abstract}

